\title{
BAPTISTA, Paulo Agostinho N. Libertação e Ecologia: a teologia teoantropocósmica de Leonardo Boff. São Paulo: Paulinas, 2011.
}

João Batista Libanio*

L. Boff alinha-se entre os teólogos mais produtivos do Continente e quiçá do mundo, não só em quantidade de obras, como também em diversidade temática. Não faz parte dos especialistas de uma nota só, mas transita em muitos campos da teologia e afins. Une ao rigor do pensamento acadêmico a leveza franciscana de muitos escritos que escapam a fácil enquadramento teórico. Isso dificulta muito aos estudiosos sistematizá-lo. Paulo Agostinho ousou fazê-lo e o conseguiu de maneira excelente.

O livro inscreve-se na coleção Interface na qual a Editora Paulinas e a SOTER começaram a publicar teses doutorais premiadas em primeiro lugar entre as que se apresentaram para a seleção. Assim essa obra na Assembléia da SOTER de 2010 foi considerada a de maior valor e por isso a editora a publicou. Já essa escolha a recomenda altamente.

O autor demonstrou, com extrema clareza e pertinência, a relação entre a teologia da libertação de BOFF e a teologia do pluralismo religioso, ao estudar-lhe a evolução do pensamento, cuja virada importante se deu entre os anos 1990/1993. O paradigma ecológico cumpriu a função de articulação entre ambas. Fez assim jus às exigências de tese doutoral, na originalidade de tal articulação, em relação aos inúmeros estudos até então feitos sobre BOFF.

Conseguiu equilíbrio entre o percurso diacrônico das obras de BOFF e eixos sistemáticos e hermenêuticos, sem perder-se em minúcias exegéticas dos seus textos. Para isso, o autor escolheu categorias centrais da teologia de BOFF com interpretação enriquecedora. A leitura sistemática do pensamento de BOFF prepara o estudioso para entender-lhe as diferentes obras.

\footnotetext{
* Doutor em Teologia (Gregoria-Roma) e professor da FAJE (Faculdade Jesuíta de Filosofia e Teologia). País de origem: Brasil. E-mail: secteologia@faculdadejesuita.edu.br
} 
No primeiro capítulo, estuda os primeiros escritos de BOFF até 1990/1993, quando percebe no teólogo certa virada. Contextualizou a teologia da libertação e a teologia do pluralismo religioso no campo sócio-político, cultural e eclesial-teológico. Ambas se consideram teologias contextuais. Paulo Agostinho privilegiou a globalização e a pósmodernidade do lado sociocultural, e o Concílio Vaticano II e os teólogos a ele vinculados, do lado eclesial. Talvez tenha descuidado dois aspectos importantes: o neoliberalismo no campo econômico e o midiático no cultural. Explicita bem a relação entre contextualização e universalidade da teologia.

Percorreu os textos de BOFF sob as duas perspectivas do limite e da abertura em relação ao diálogo inter-religioso. Interpretação original, rica e heurística, cuidando, porém, de não cair no anacronismo. Indo além daquilo que BOFF explícita e reflexamente expusera, escavou camadas subjacentes, idéias presentes de maneira embrionária.

Mostrou os limites dos escritos cristológicos, eclesiológicos e antropológicos em relação ao diálogo inter-religioso com eventuais explicitações e explicações. Apareceu bem como BOFF se entende situado no momento histórico das décadas de 70 e 80, antes da ruptura da década seguinte. Os limites lhe eram impostos pela cultura e teologia circundantes.

Em outro momento, fez o percurso oposto, ao exibir-lhes as aberturas, ampliando os campos estudados nos parágrafos anteriores - cristologia, eclesiologia e antropologia - para outros como teologia trinitária e espiritualidade.

Terminou com balanço conclusivo. E apontou também as virtualidades teológicas de mudança em direção ao pluralismo religioso em exame crítico.

O segundo capítulo aborda a mudança de paradigma de BOFF que possibilita a passagem da sua teologia anterior para o cerne e objetivo principal da pesquisa que se abordará no capítulo seguinte.

Paulo Agostinho escolheu a categoria de mudança de paradigma. Para isso, elaborou com ajuda de teólogos o conceito de paradigma. Antes, porém, fez bem de mostrar como o conceito nasceu nas ciências exatas e foi apropriado pela teologia, especialmente por KÜNG, exatamente no contexto do diálogo ecumênico. Fez cuidadosa elaboração do conceito paradigma, mostrando os movimentos a que foi submetido até chegar aonde queria: paradigma interpretado em vista da teologia da libertação e da 
teologia do pluralismo religioso. Quanto a esta última, expôs bem as condições socioculturais que lhe permitiram o surgir e entrou no emaranhado de divisões e subdivisões no interior do paradigma da teologia do pluralismo religioso. E o fez com clareza e precisão, ao mostrar os avanços das diferentes propostas e seus defensores.

Depois de longa preparação semântica, Paulo Agostinho aterrissou na teologia de BOFF, trabalhando, de início, o significado de paradigma ecológico, as bases teóricas e dimensões nas suas obras. O termo nasce na sua literalidade na obra de 1993 e aparece como subtítulo do livro: "Ecologia, mundialização, espiritualidade: a emergência de um novo paradigma". Termo que será realmente analisado mais tarde, em 1995, embora textos precedentes o adumbrem. Situou-o no processo da criação do novo paradigma científico, ao analisar série de autores que estiveram na sua origem. BOFF o caracteriza em dez pontos no livro Dignitas Terrae. Ao pôr-se sob tal paradigma, a sua teologia sofreu a inflexão que Paulo Agostinho analisou muito bem, percorrendo-lhe a cosmologia, a antropologia, a compreensão de Deus, o Espírito Santo, Cristo e a Trindade e a eclesiologia. Apontou-lhe avaliações e observações críticas. $\mathrm{O}$ autor forjou, de maneira original e pertinente, a categoria teoantropocósmica para definir a posição de BOFF. Ela surge das mudanças apontadas no tríplice âmbito do cosmos, do ser humano e de Deus numa inter-relação nova.

Paulo Agostinho percebeu com profundidade, acuidade e perspicácia tal virada. Aqui está um dos grandes méritos da pesquisa. Não é fácil captar as viradas de pensamento, sobretudo quando o autor as faz de maneira quase natural, sem ele mesmo marcar a ruptura. Esta depende da capacidade interpretativa do estudo e nasce de leitura detalhada e completa do autor estudado.

Com o terceiro capítulo, chegamos ao coração da pesquisa que foi bem preparado pelas partes anteriores. Mostra a enorme atualidade do pensamento de BOFF, sua capacidade de perceber os novos sinais dos tempos, sem perder opções básicas iniciais ainda válidas.

Esse capítulo conclusivo, embora mais breve, fundamenta a teologia teoantropocósmica de BOFF como a articulação entre a teologia da libertação e a teologia do pluralismo religioso. Nessa teologia, libertação e diálogo se encontram. A concepção teoantropocósmica qualifica, torna inteligível a produção teológica de BOFF no paradigma ecológico. 
A teologia teoantropocósmica oferece concepções propiciadoras de encontro e dialogação, uma práxis libertadora e do pluralismo religioso. Paulo Agostinho a classificou como pertencendo ao pluralismo inclusivo ou "pluralismo inclusivo teoantropocósmico", uma teologia pluralista da libertação. Inclusivo porque parte da revelação e experiência cristã. Mas implica uma cristologia aberta, cuja salvação carrega significação profunda e aberta, cósmica, não só para o cristão. Descentra a eclesiologia. Interessam antes a BOFF a espiritualidade e suas múltiplas formas de expressão.

Tal teologia amplia o Cristianismo para a dimensão do universalizável além da inculturação ocidental. BOFF estuda-o na relação com as religiões na perspectiva teoantropocósmica. Mostra a articulação da libertação e o pluralismo religioso. O livro termina refletindo sobre a realidade do diálogo e suas práticas concretas: oração, fraternidade e ética do cuidado, da compaixão.

O paradigma ecológico abriu a produção teológica de BOFF para a teologia do pluralismo religioso, ao oferecer-lhe perspectiva inter-relacional, teoantropocósmica. Mas antes já existiam sinais de abertura, tanto no momento prévio a abraçar a teologia da libertação, como, de modo crescente, no seu processo e, principalmente depois que adota o paradigma ecológico. A teologia teoantropocósmica é libertadora e pluralista religiosa. Promove a religação entre as religiões.

Além do conhecimento exaustivo do autor, o livro mostrou ampla informação complementar, assimilada e elaborada, sobre os dois temas centrais da teologia da libertação e da teologia do pluralismo religioso. Impressiona a bibliografia consultada, citada, referida. Calçou bem as afirmações, explicitou conceitos, completou asserções.

Trata-se de estudo extremamente minucioso que recorre a múltiplas fontes, sopesando-as com clarividência e criticidade. Em excelente reflexão e capacidade de distinção, retirou de uma mesma categoria, p. ex., pobre, libertação, aspectos de limite e de abertura.

Para quem pensa em estudos ulteriores sobre BOFF, encontra já nessa obra ampla bibliografia. Portanto, livro fundamental e imprescindível para o conhecimento do pensamento do BOFF. 